\title{
ANALISIS KEPUASAN KONSUMEN PEDAGANG LANGKITANG KAKI LIMA DI KAWASAN OBJEK WISATA PANTAI PADANG
}

\author{
Hafrizal Okta Ade Putra \\ Dosen Fakultas Ekonomi Universitas Tamansiswa Padang \\ Email: hafrizalokta@gmail.com \\ Yuni Candra \\ Dosen Fakultas Ekonomi Universitas Tamansiswa Padang \\ Email: yuni.candra80@gmail.com
}

\begin{abstract}
The purpose of this research is to know and analyze, (1) the influence of food quality to the satisfaction of the merchant of Langkitang in Padang beach resort area; (2) the influence of price to the satisfaction of the merchant of Langkitang in Padang beach resort area, 3) the influence of food quality and price simultaneously to the satisfaction of merchant consumers Langkitang pavement in the area of Padang Beach tourist attraction. Population in this research is all consumer of Langkitang merchant of pavement in Padang beach resort area. The number of samples in this study is 100 respondents which use accidental sampling technique. Based on the result of the research, it can be seen that: (1) The quality of food has a significant effect on the satisfaction of the consumers in the street vendors in Padang Beach tourist area, where $t$-count 2,685 from $t$-table 1,661 and significance 0,009 less than level of significant $(\alpha)$ 0.05. (2) Price has a significant effect to customer satisfaction at Langkitang street vendors in Padang Beach tourist area, where t-count 2,564>t-table 1,661 and significance $0.012<$ level of significant $(\alpha) 0,05$. (3) The quality of food and the price simultaneously have a significant effect on the satisfaction of the consumers on the street vendors in Padang Beach, where F-count is $19.496>$ F-table 3.09 and the significance of 0.000 is $<$ the level of significant $(\alpha) 0.05$. (4) The coefficient of determination is 0,272, mean than food quality and price influence consumer satisfaction at trader Langkitang pavement in coastal resort area of Padang equal to $27,2 \%$.
\end{abstract}

Key word : Langkitang, street vendors, Padang Beach tourist area, food quality,price, and consumer satisfaction.

\section{PENDAHULUAN}

\subsection{Latar Belakang}

Pariwisata dapat berkontribusi besar terhadap perekonomian daerah. Mewujudkan daya tarik pariwisata sebagai suatu kekuatan ekonomi untuk Sumatera Barat, merupakan sebuah tema pembahasan yang cukup komplit. Diperlukan pembenahan secara komprehensif terhadap objek kajian bagaimana mengelola pariwisata tersebut.

"Alam Sumatera Barat diciptakan saat Tuhan tersenyum, ..." seloroh mantan Wakil Menteri Pariwisata dan Ekonomi Kreatif, Sapta Nirwandar memuji keelokan alam Minangkabau. Apa yang disampaikan oleh Bapak Sapta itu, Penulis rasa tidaklah berlebihan. Obyek wisata alam jenis apa pun tersedia di Sumatera Barat, mulai dari 
pantai indah yang berpasir putih, pantai berombak tinggi untuk surfing, pegunungan dengan udara segar, perbukitan, air terjun, goa, danau, sungai, lembah dan ngarai.

Tidak ketinggalan, tentu saja wisata kuliner yang khas dari Sumatera Barat, dengan pilihan yang sangat beragam. Selain rendang yang dinobatkan sebagai hidangan peringkat pertama dalam daftar world's 50 most delicious foods yang digelar oleh CNN International (Cheung, 2011), wisatawan bisa menikmati gulai itik lado hijau, aneka samba lado, tambunsu, gajeboh, ampiang dadiah, minuman khas kawa daun dan teh telur, serta masih banyak lagi jajanan-jajanan kuliner kaki lima lainnya.

Dalam Peraturan Menteri Dalam Negeri Nomor 41 Tahun 2012 tentang Pedoman Penataan dan Pemberdayaan Pedagang Kaki Lima yang dimaksud dengan Pedagang Kaki Lima atau disingkat PKL, adalah pelaku usaha yang melakukan usaha perdagangan dengan menggunakan sarana usaha bergerak maupun tidak bergerak, menggunakan prasarana kota, fasilitas sosial, fasilitas umum, lahan, dan bangunan milik pemerintah dan atau swasta yang bersifat sementara atau tidak menetap.

Tiap negara, menurut Bondan Winarno, memiliki jajanan khas kaki lima. Seperti New York dengan hot dog, pretzel, hingga sosis. Kini bahkan berkembang menjadi food truck khusus muslim (halal) di Amerika. Semua itu menjadi budaya masyarakat setempat. Di Indonesia sangat mudah ditemukan pedagang makanan kaki lima. Sayangnya, pedagang penggerak ekonomi ini kurang mendapat perhatian pemerintah. Seperti belum adanya data statistik lengkap tentang pedagang kaki lima. Ini menunjukkan perhatian pemerintah yang masih kurang. Sekitar 85 persen makanan di dunia tersedia di jalanan. Khusus di Indonesia saja, ada lebih dari 50 persen pedagang kecil menjual makanan. Pada saat ini diperkirakan ada 45 juta pedagang kecil. Dengan angka estimasi 20 juta pedagang saja, sudah dapat menggerakkan putaran ekonomi dari hulu ke hilir (Sari, 2013).

Pengamatan Penulis di objek wisata Pantai Padang, setiap sore hari, banyak ditemukan pedagang kaki lima yang menjual Langkitang. Bagi masyarakat di Sumatera Barat, khususnya Kota Padang, atau orang-orang yang pernah berkunjung ke Kota Padang, Langkitang mungkin sudah tidak asing lagi di telinga mereka. Langkitang adalah salah satu makanan khas Minang, hewan bercangkang, menyerupai keong, berwarna hitam, berukurakan kurang dari $4 \mathrm{CM}$, dimasak dengan cara digulai (campuran santan, cabe, dan bumbu rempah khas Minang lainnya), dan terasa pedas.

Pedagang kaki lima yang menjual Langkitang di Pantai Padang selalu ramai dikunjungi wisatawan. Mereka bukan saja datang dari Kota Padang dan luar Kota Padang, tapi juga datang dari luar Sumatera Barat untuk menikmati Langkitang sambil melihat keindahan pantai dan sunset. Harga Langkitang pun cukup terjangkau, yaitu berkisar antara Rp. 5.000,- sampai dengan Rp. 10.000,- per bungkus, walaupun masih ada beberapa pedagang yang "nakal" dengan seenaknya saja memberi harga kepada konsumen.

\subsection{Rumusan Masalah}

Berdasarkan uraian latar belakang di atas maka permasalahan penelitian dapat dirumuskan sebagai berikut :

1. Bagaimanakah pengaruh kualitas makanan terhadap kepuasan konsumen pedagang Langkitang kaki lima di kawasan objek wisata Pantai Padang?

2. Bagaimanakah pengaruh harga terhadap kepuasan konsumen pedagang Langkitang kaki lima di kawasan objek wisata Pantai Padang? 
3. Bagaimanakah pengaruh kualitas makanan dan harga secara simultan terhadap kepuasan konsumen pedagang Langkitang kaki lima di kawasan objek wisata Pantai Padang?

\section{LANDASAN TEORI}

\subsection{Kepuasan Konsumen}

Secara umum, kepuasan (satisfaction) adalah perasaan senang atau kecewa seseorang yang timbul karena membandingkan kinerja yang dipersepsikan produk (atau hasil) terhadap ekspektasi mereka (Kotler dan Keller, 2009:138-139). Menurut Oliver dalam Barner (2001:64), kepuasan adalah tanggapan konsumen atas terpenuhinya kebutuhannya.

Ada sejumlah metode untuk mengukur kepuasan konsumen. Survei berkala dapat melacak kepuasan pelanggan secara langsung, mengajukan pertanyaan tambahan untuk mengukur niat atau kemungkinan untuk melakukan pembelian kembali, dan kesediaan responden untuk merekomendasikan suatu perusahaan atau merek kepada orang lain (Kotler dan Keller, 2009:140).

Menurut Kotler dan Keller (2009), kepuasan seorang konsumen tergantung pada kualitas produk dan jasa. Semakin tinggi tingkat kualitas, semakin tinggi tingkat kepuasan konsumen yang dihasilkan, yang mendukung harga yang lebih tinggi dan (sering kali) biaya yang lebih rendah. Kualitas jelas merupakan kunci untuk menciptakan nilai dan kepuasan konsumen.

Faktor yang menentukan kepuasan (Lovelock dan Wirtz, 2011) :

1. Harapan pelanggan adalah ketika pelanggan memutuskan untuk membeli suatu layanan tertentu.

2. Penilaian kepuasan pelanggan. Menilai penyelanggaraan layanan dengan membandingkan apa yang mereka harapkan dengan apa yang mereka pikir mereka dapatkan dari penyedia layanan tertentu.

\subsection{Kualitas Makanan}

Kualitas (quality) adalah totalitas fitur dan karakteristik produk atau jasa yang bergantung pada kemampuannya untuk memuaskan kebutuhan yang dinyatakan atau tersirat (Kotler dan Keller, 2009:143). Produk adalah segala sesuatu yang dapat ditawarkan kepada pasar untuk memuaskan suatu keinginan atau kebutuhan, termasuk barang fisik, jasa, pengalaman, acara, orang, tempat, properti, organisasi, informasi, dan ide (Kotler dan Keller, 2009:4).

Menurut Potter dan Hotchkiss (dalam Fiani dan Japarianto, 2012:1) kualitas makanan adalah karakteristik kualitas dari makanan yang dapat diterima oleh konsumen. Ini termasuk dalam faktor eksternal seperti ukuran, bentuk, warna, konsistensi, tekstur, dan rasa. Menurut West, Wood, dan Harger (2006:39), Gaman dan Sherrington (1996:132) serta Jones (2000:109-110) (dalam Fiani dan Japarianto, 2012:1-2), secara garis besar faktor-faktor yang mempengaruhi food quality adalah sebagai berikut :

1. Warna: Warna dari bahan-bahan makanan harus dikombinasikan sedemikian rupa supaya tidak terlihat pucat atau warnanya tidak serasi. Kombinasi warna sangat membantu dalam selera makan konsumen.

2. Penampilan: Ungkapan looks good enough to eat bukanlah suatu ungkapan yang berlebihan. Makanan harus baik dilihat saat berada di piring, di mana hal tersebut adalah suatu faktor yang penting. Kesegaran dan kebersihan dari 
makanan yang disajikan adalah contoh penting yang akan mempengaruhi penampilan makanan baik atau tidak untuk dinikmati.

3. Porsi: Dalam setiap penyajian makanan sudah ditentukan porsi standarnya yang disebut standard portion size. Standard portion size didefinisikan sebagai kuantitas item yang harus disajikan setiap kali item tersebut dipesan. Manajemen dianjurkan untuk membuat standard portion size secara jelas, misalnya berapa gram daging yang harus disajikan dalam sebuah porsi makanan.

4. Bentuk: Memainkan peranan penting dalam daya tarik mata. Bentuk makanan yang menarik bisa diperoleh lewat cara pemotongan bahan makanan yang bervariasi, misalnya wortel yang dipotong dengan bentuk dice atau biasa disebut dengan potongan dadu digabungkan dengan selada yang dipotong chiffonade yang merupakan potongan yang tidak beraturan pada sayuran.

5. Temperatur: Konsumen menyukai variasi temperatur yang didapatkan dari makanan satu dengan lainnya. Temperatur juga bisa mempengaruhi rasa, misalnya rasa manis pada sebuah makanan akan lebih terasa saat makanan tersebut masih hangat, sementara rasa asin pada sup akan kurang terasa pada saat sup masih panas.

6. Tekstur: Ada banyak tekstur makanan antara lain halus atau tidak, cair atau padat, keras atau lembut, kering atau lembab. Tingkat tipis dan halus serta bentuk makanan dapat dirasakan lewat tekanan dan gerakan dari reseptor di mulut.

7. Aroma: Reaksi dari makanan yang akan mempengaruhi konsumen sebelum konsumen menikmati makanan, konsumen dapat mencium makanan tersebut.

8. Tingkat kematangan: Akan mempengaruhi tekstur dari makanan. Misalnya wortel yang direbus cukup akan menjadi lunak daripada wortel yang direbus lebih cepat. Untuk makanan tertentu seperti steak setiap orang memiliki selera sendiri-sendiri tentang tingkat kematangan steak.

9. Rasa: Titik perasa dari lidah adalah kemampuan mendeteksi dasar yaitu manis, asam, asin, pahit. Dalam makanan tertentu empat rasa ini digabungkan sehingga menjadi satu rasa yang unik dan menarik untuk dinikmati.

\subsection{Harga}

Harga adalah salah satu elemen bauran pemasaran yang menghasilkan pendapatan (elemen lain menghasilkan biaya). Harga adalah elemen termudah dalam program pemasaran untuk disesuaikan (fitur produk, saluran, dan bahkan komunikasi membutuhkan lebih banyak waktu). Harga juga mengkomunikasikan positioning nilai yang dimaksudkan dari produk atau merek perusahaan ke pasar. Produk yang dirancang dan dipasarkan dengan baik dapat dijual dengan harga tinggi dan menghasilkan laba yang besar (Kotler dan Keller, 2009:67).

Pemasar menyadari bahwa konsumen sering memproses informasi harga secara aktif, menerjemahkan harga berdasarkan pengetahuan mereka dari pengalaman pembelian mereka sebelumnya, komunikasi formal, komunikasi informal, atau faktor lainnya. Keputusan pembelian didasarkan pada bagaimana konsumen menganggap harga dan berapa harga aktual saat ini yang mereka pertimbangkan, bukan harga yang dinyatakan pemasar. Konsumen mungkin memiliki batas bawah harga di mana harga yang lebih rendah dari batas itu menandakan kualitas buruk atau kualitas yang tidak dapat diterima, dan juga batas atas harga yang di mana harga yang lebih tinggi dari batas itu dianggap terlalu berlebihan dan tidak sebanding dengan uang yang dikeluarkan (Kotler dan Keller, 2009:67). 
Beberapa indikator harga menurut Kertajaya (2007) :

1. Kesesuaian harga produk dengan kualitas: Harga produk yang ditawarkan sebanding dengan kualitas produk yang ditawarkan.

2. Perbandingan harga dengan harga produk sejenis: Harga barang tidak mahal jika dibandingkan dengan produk barang yang nilai gunanya sama.

3. Kesesuaian harga produk dengan manfaat yang didapat: Harga sesuai dengan nilai kegunaan produk yang ditawarkan.

\subsection{Tujuan Penelitian}

Tujuan dilakukannya penelitian ini adalah :

1. Untuk mengetahui dan menganalisa pengaruh kualitas makanan terhadap kepuasan konsumen pedagang Langkitang kaki lima di kawasan objek wisata Pantai Padang.

2. Untuk mengetahui dan menganalisa pengaruh harga terhadap kepuasan konsumen pedagang Langkitang kaki lima di kawasan objek wisata Pantai Padang.

3. Untuk mengetahui dan menganalisa pengaruh kualitas makanan dan harga secara simultan terhadap kepuasan konsumen pedagang Langkitang kaki lima di kawasan objek wisata Pantai Padang.

\section{METODE PENELITIAN}

\subsection{Ruang Lingkup Penelitian}

Penelitian ini mendeskripsikan pengaruh dari kualitas makanan dan harga terhadap kepuasan konsumen pedagang Langkitang kaki lima di kawasan objek wisata Pantai Padang. Objek dalam penelitian ini adalah konsumen pedagang Langkitang kaki lima di kawasan objek wisata Pantai Padang. Jenis penelitian yang penulis lakukan termasuk penelitian deskriptif korelasi, di mana penelitian ini menjelaskan, menggambarkan, serta memperlihatkan hubungan sebab akibat antar variabelnya. Sebagai konsep untuk menjelaskan, mengungkapkan, dan menentukan persepsi keterkaitan antara variabel-variabel yang akan diteliti, berdasarkan permasalahan maupun antara variabel yang berpijak dari berbagai teori, maka secara konseptual dapat

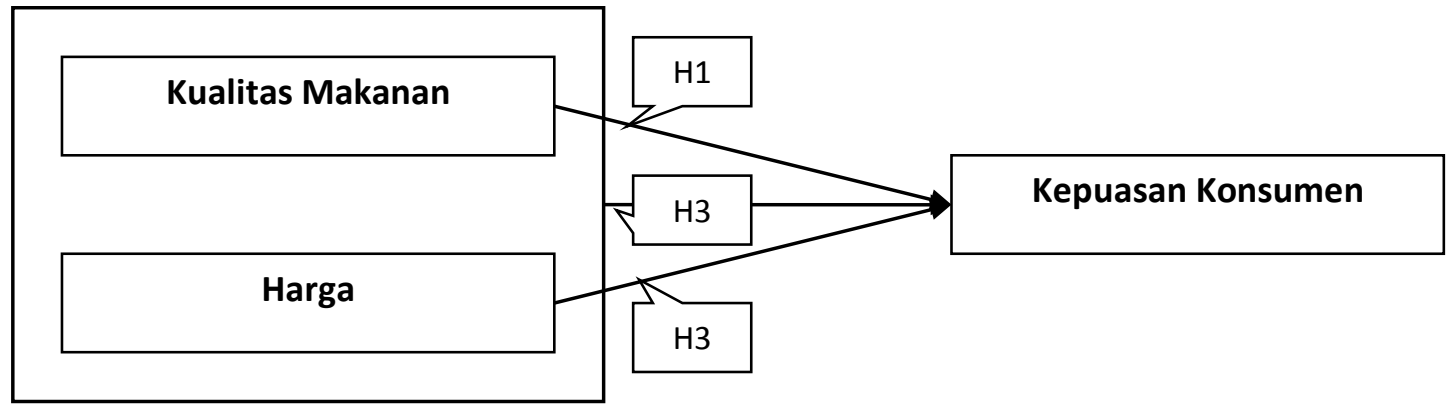

digambarkan sebagai berikut :

\section{Gambar 1. Kerangka Konseptual}

\subsection{Populasi dan Sampel}

Dalam penelitian ini yang menjadi populasinya adalah seluruh konsumen pedagang makanan kaki lima di kawasan objek wisata Pantai Padang. Sampel adalah bagian dari populasi yang dianggap cukup mewakili. Pengambilan sampel menggunakan non-probability sampling, di mana setiap unsur yang ada dalam populasi tidak memiliki kesempatan atau peluang yang sama untuk dipilih sebagai sampel. 
Teknik pengambilan sampel dilakukan dengan accidental sampling, yaitu dengan penetapan jumlah terhadap konsumen yang mudah ditemui pada saat survei dilakukan (Sugiyono, 2004:77).

Roscoe (1975) yang dikutip Sekaran (2006) memberikan acuan umum untuk menentukan ukuran sampel, yaitu ukuran sampel lebih dari 30 dan kurang dari 500 adalah tepat untuk kebanyakan penelitian. Untuk penelitian ini Penulis memutuskan untuk menetapkan jumlah sampel sebanyak 100 orang responden.

\subsection{Teknik Pengumpulan Data}

1. Kuesioner: Metode yang digunakan untuk mendapatkan data primer dengan cara membuat daftar pernyataan yang secara sistematik dengan tujuan mendapatkan data yang diinginkan. Daftar pernyataan diedarkan kepada responden untuk dijawab.

2. Dokumentasi: Metode yang digunakan untuk mendapatkan data yang bersumber kepada tulisan, seperti buku yang relevan dengan penelitian, jurnal, majalah, dari internet atau website serta data-data lain yang berhubungan dengan penelitian ini.

\subsection{Instrumen Penelitian}

Instrumen untuk mengumpulkan data dalam penelitian ini adalah dengan menggunakan beberapa pernyataan (kuesioner) yang disusun menggunakan skala Likert. Skala Likert adalah skala yang digunakan secara luas yang meminta responden menandai derajat persetujuan atau ketidaksetujuan terhadap masing-masing dari serangkaian pernyataan mengenai objek stimulus (Malhotra, 2005:298). Setiap pernyataan mempunyai lima alternatif jawaban yang dapat dilihat pada tabel berikut ini

Tabel 1. Instrumen Penelitian (Skala Likert)

\begin{tabular}{ccc} 
No. & Kategori & Skor \\
\hline 1. & Sangat Setuju & 5 \\
2. & Setuju & 4 \\
3. & Biasa Saja & 3 \\
4. & Tidak Setuju & 2 \\
5. & Sangat Tidak Setuju & 1 \\
\hline
\end{tabular}

Untuk memastikan instrumen yang digunakan dalam penelitian ini merupakan alat ukur yang akurat dan dapat dipercaya, maka digunakan dua macam pengujian.

1. Uji Validitas

Uji validitas digunanakan untuk mengukur sah atau valid tidaknya suatu kuesioner (Ghozali, 2005:45). Suatu kuesioner dikatakan valid jika pertanyaan pada kuesioner mampu untuk mengungkapkan sesuatu yang akan diukur oleh kuesioner tersebut.

Uji validitas digunakan dengan membandingkan antara nilai $r_{\text {hitung }}$ dengan $r_{\text {tabel }}$. Jika nilai $r_{\text {hitung }}>r_{\text {tabel }}$ dan bernilai positif maka instrument tersebut dikatakan valid. Untuk degree of freedom $(d f)=\mathrm{N}-2$, dalam hal ini $\mathrm{N}$ adalah jumlah sampel. Suatu indikator dikatakan valid, apabila $d f=\mathrm{N}-2=100-2=98$ dan $\alpha=$ $5 \%$, maka $r_{\text {tabel }}=0,1966$ (Ghozali, 2005:45).

2. Uji Reliabilitas 
Uji reliabilitas adalah alat untuk mengukur suatu kuesioner yang merupakan indikator dari variabel atau konstruk (Ghozali, 2005:41). Suatu kuesioner dikatakan reliabel jika jawaban seseorang terhadap pernyataan adalah konsisten atau stabil dari waktu ke waktu. Jawaban responden terhadap pernyataan ini dikatakan reliabel jika masing-masing pertanyaan dijawab secara konsisten. Alat untuk mengukur reliabilitas adalah Alpha Cronbach. Suatu variabel dikatakan reliabel, apabila Alpha Cronbach > 0,600 (Ghozali, 2005:42).

Untuk mengetahui nilai uji validitas dan uji reliabilitas, maka pengolahan data dilakukan pengujian dengan menggunakan program software SPSS versi 20.

\subsection{Teknik Analisis Data}

1. Uji Normalitas Data dan Analisis Deskriptif

a. Uji Normalitas Data

Uji normalitas data dimaksudkan untuk memperoleh kapasitas bahwa populasi tersebar secara normal. Uji normalitas dilakukan dengan menggunakan grafik normal probability plot. Persyaratan normalitas terpenuhi jika nilai-nlai sebaran data terletak disekitar garis lurus (Santoso, 2003). Bila tersebar secara normal, berarti sampel yang diambil mewakili populasi.

b. Analisis Deskriptif

Setelah data terkumpul kemudian disajikan ke dalam tabel distribusi frekuensi untuk dilakukan analisis deskriptif. Analisis ini digunakan untuk melihat gambaran secara umum tentang variabel yang diteliti dengan analisis persentase. Untuk mencari persentase jawaban angket dari responden digunakan rumus :

$\mathrm{P}=\mathrm{f} / \mathrm{n} \times 100 \%$

Di mana: $\quad \mathrm{P}=$ Persentase yang dicari

$\mathrm{f}=$ Frekuensi

$\mathrm{n}=$ Jumlah responden

Untuk menghitung rata-rata skor masing-masing item digunakan rumus sebagai berikut :

$$
\mathrm{X}_{w}=\frac{\sum f_{i} w_{i}}{\sum f_{i}}
$$

$$
\begin{array}{rll}
\text { Keterangan : } & \text { SS }=\text { Sangat Setuju } & \text { TS = Tidak Setuju } \\
\text { S }=\text { Setuju } & \text { STS }=\text { Sangat Tidak Setuju } \\
\text { BS }=\text { Biasa Saja } &
\end{array}
$$

Menghitung nilai TCR dari masing-masing kategori jawaban dari deskriptif variabel, maka dapat dihitung dengan menggunakan rumus sebagai berikut :

$\mathrm{TCR}=\mathrm{Rs} / \mathrm{n} \times 100 \%$

Di mana : $\quad$ TCR $=$ Tingkat capaian responden

Rs = Rata-rata skor jawaban responden

$\mathrm{n} \quad=$ Jawaban responden 
Pengkategorian nilai pencapaian responden digunakan klasifikasi :

$\begin{array}{llll}90 \%-100 \% & \text { Sangat baik } & 55 \%-64 \% & \text { Buruk } \\ 80 \%-89 \% & \text { Baik } & 0 \%-54 \% & \text { Sangat buruk } \\ 65 \%-79 \% & \text { Sedang } & & \end{array}$

\subsection{Metode Analisis Data}

1. Uji Regresi

Uji regresi linear berganda adalah sebuah pengujian statistik untuk mendapatkan gambaran pengaruh dari variabel independent terhadap variabel dependent. Santoso (2003) secara umum merumuskan regresi linear sederhana sebagai berikut :

$\mathrm{Y}=\mathrm{a}+\mathrm{b}_{1} \mathrm{X}_{1}+\mathrm{b}_{2} \mathrm{X}_{2}+\mathrm{e}$

$$
\text { Keterangan: } \quad \begin{array}{ll}
\mathrm{Y} & =\text { Kepuasan konsumen } \\
& \mathrm{b}_{1}, \mathrm{~b}_{2}=\text { Koefisien regresi } \\
\mathrm{X}_{1} & =\text { Kualitas makanan } \\
\mathrm{X}_{2} & =\text { Harga } \\
\mathrm{e} & =\text { Disturbance error }
\end{array}
$$

2. Uji t

Menerapkan suatu uji statistik yang digunakan untuk melihat pengaruh variabel independent terhadap variabel dependent secara parsial. Pengujian hipotesis dilakukan dengan menggunakan t-test dengan menggunakan program software SPSS versi 20.

3. Uji F

Uji F digunakan untuk melihat pengaruh variabel independent terhadap variabel dependent secara simultan. Pengujian hipotesis dilakukan dengan menggunakan F-test. Untuk mendapatkan hasil $F_{\text {hitung, pengolahan data dilakukan }}$ menggunakan program software SPSS versi 20.

4. Koefisien Determinasi $\left(\mathrm{R}^{2}\right)$

Koefisien determinasi adalah salah satu nilai statistik yang dapat digunakan untuk mengetahui apakah ada hubungan pengaruh antara dua variabel. Nilai koefisien determinasi menunjukkan persentase nilai variabel dependent yang dapat dijelaskan oleh persamaan regresi yang dihasilkan. Besarnya persentase pengaruh semua variabel independent terhadap nilai variabel dependent dapat diketahui dari besarnya koefisien determinasi $\left(\mathrm{R}^{2}\right)$ persamaan regresi. Untuk mendapatkan hasil $\mathrm{R}^{2}$, pengolahan data dilakukan menggunakan program software SPSS versi 20.

\section{HASIL DAN PEMBAHASAN}

\subsection{Identitas Responden}

Berdasarkan hasil tabulasi kuisioner penelitian dapat diketahui identitas responden sebagai berikut :

1. Jenis Kelamin Responden

Identitas responden berdasarkan jenis kelamin : 
Tabel 2. Jenis Kelamin Responden

\begin{tabular}{|c|c|c|c|c|c|}
\hline & & Frequency & Percent & Valid Percent & $\begin{array}{l}\text { Cumulative } \\
\text { Percent }\end{array}$ \\
\hline \multirow[t]{3}{*}{ Valid } & Laki-laki & 43 & 43.0 & 43.0 & 43.0 \\
\hline & Perempuan & 57 & 57.0 & 57.0 & 100.0 \\
\hline & Total & 100 & 100.0 & 100.0 & \\
\hline
\end{tabular}

Sumber: Data diolah, 2017.

2. Usia Responden

Pengelompokkan identitas responden berdasarkan usia :

Tabel 3. Usia Responden

\begin{tabular}{|ll|r|r|r|r|}
\hline & Frequency & Percent & Valid Percent & \multicolumn{2}{c|}{$\begin{array}{c}\text { Cumulative } \\
\text { Percent }\end{array}$} \\
\hline Valid & $<18$ tahun & 21 & 21.0 & 21.0 & 21.0 \\
& $18-25$ tahun & 38 & 38.0 & 38.0 & 59.0 \\
$26-40$ tahun & 26 & 26.0 & 26.0 & 85.0 \\
$40-60$ tahun & 11 & 11.0 & 11.0 & 96.0 \\
$>61$ tahun & 4 & 4.0 & 4.0 & 100.0 \\
Total & 100 & 100.0 & 100.0 & \\
\hline
\end{tabular}

Sumber: Data diolah, 2017.

3. Pendidikan Terakhir Responden

Pengelompokkan identitas responden berdasarkan pendidikan terakhir :

Tabel 4. Pendidikan Terakhir Responden

\begin{tabular}{|ll|r|r|r|r|}
\hline & Frequency & Percent & Valid Percent & \multicolumn{2}{c|}{$\begin{array}{c}\text { Cumulative } \\
\text { Percent }\end{array}$} \\
\hline Valid & SMA Sederajat & 51 & 51.0 & 51.0 & 51.0 \\
& Diploma & 10 & 10.0 & 10.0 & 61.0 \\
S1 & 19 & 19.0 & 19.0 & 80.0 \\
S2 & 6 & 6.0 & 6.0 & 86.0 \\
Lainnya & 14 & 14.0 & 14.0 & 100.0 \\
Total & 100 & 100.0 & 100.0 & \\
\hline
\end{tabular}

Sumber: Data diolah, 2017.

4. Pekerjaan Responden

Pengelompokkan identitas responden berdasarkan pekerjaan :

Tabel 5. Pekerjaan Responden

\begin{tabular}{|ll|r|r|r|r|}
\hline & Frequency & Percent & Valid Percent & \multicolumn{2}{|c|}{$\begin{array}{c}\text { Pumulative } \\
\text { Percent }\end{array}$} \\
\hline Valid & Pelajar & 18 & 18.0 & 18.0 & 18.0 \\
& Mahasiswa & 27 & 27.0 & 27.0 & 45.0 \\
& PNS & 11 & 11.0 & 11.0 & 56.0 \\
& Karyawan Swasta & 18 & 18.0 & 18.0 & 74.0
\end{tabular}


Polibisnis, Volume 9 No. 2 Oktober 2017

\begin{tabular}{|l|r|r|r|r|}
\hline Wiraswasta & 14 & 14.0 & 14.0 & 88.0 \\
Lainnya & 12 & 12.0 & 12.0 & 100.0 \\
Total & 100 & 100.0 & 100.0 & \\
\hline
\end{tabular}

Sumber: Data diolah, 2017.

5. Pendapatan Responden

Pengelompokkan identitas responden berdasarkan pendapatan :

Tabel 6. Pendapatan Responden

\begin{tabular}{|c|c|c|c|c|c|}
\hline & & Frequency & Percent & Valid Percent & $\begin{array}{l}\text { Cumulative } \\
\text { Percent }\end{array}$ \\
\hline \multirow[t]{6}{*}{ Valid } & < Rp. 1.950.000,- & 48 & 48.0 & 48.0 & 48.0 \\
\hline & $\begin{array}{l}\text { Rp. 1.950.001,- s/d Rp. } \\
\text { 3.000.000,- }\end{array}$ & 24 & 24.0 & 24.0 & 72.0 \\
\hline & $\begin{array}{l}\text { Rp. } 3.000 .001,- \text { s/d } \\
4.500 .000,-\end{array}$ & 13 & 13.0 & 13.0 & 85.0 \\
\hline & $\begin{array}{l}\text { Rp. } 4.500 .001,- \text { s/d Rp. } \\
\text { 6.000.000,- }\end{array}$ & 11 & 11.0 & 11.0 & 96.0 \\
\hline & > Rp. 6.000.001,- & 4 & 4.0 & 4.0 & 100.0 \\
\hline & Total & 100 & 100.0 & 100.0 & \\
\hline
\end{tabular}

Sumber: Data diolah, 2017.

6. Jumlah Kunjungan Responden

Pengelompokkan identitas responden berdasarkan jumlah kunjungan ke pedagang Langkitang kaki lima di kawasan objek wisata Pantai Padang :

Tabel 7. Jumlah Kunjungan Responden

\begin{tabular}{|rl|r|r|r|r|}
\hline & & & & Cumulative \\
& & Frequency & Percent & Valid Percent \\
\hline Valid & 2 Kali & 29 & 29.0 & 29.0 & 29.0 \\
& 3 Kali & 16 & 16.0 & 16.0 & 45.0 \\
& 4 Kali & 13 & 13.0 & 13.0 & 58.0 \\
& 5 Kali & 20 & 20.0 & 20.0 & 78.0 \\
& > 5 Kali & 22 & 22.0 & 22.0 & 100.0 \\
& Total & 100 & 100.0 & 100.0 & \\
\hline
\end{tabular}

Sumber: Data diolah, 2017.

\subsection{Instrumen Penelitian}

1. Uji Validitas

Berdasarkan pengujian diperoleh hasil validitas sebagai berikut :

Tabel 8. Hasil Uji Validitas

\begin{tabular}{|c|c|c|c|c|}
\hline No. & Pernyataan & r-Hitung & r-Tabel & Ket. \\
\hline 1. & X1. 1 & 0.595 & 0.196 & Valid \\
\hline 2. & X1.2 & 0.422 & 0.196 & Valid \\
\hline
\end{tabular}




\begin{tabular}{|c|c|c|c|c|}
\hline 3. & $\mathrm{X} 1.3$ & 0.584 & 0.196 & Valid \\
\hline 4. & $\mathrm{X} 1.4$ & 0.541 & 0.196 & Valid \\
\hline 5. & $\mathrm{X} 1.5$ & 0.641 & 0.196 & Valid \\
\hline 6. & $\mathrm{X} 1.6$ & 0.676 & 0.196 & Valid \\
\hline 7. & $\mathrm{X} 1.7$ & 0.533 & 0.196 & Valid \\
\hline 8. & $\mathrm{X} 1.8$ & 0.663 & 0.196 & Valid \\
\hline 9. & $\mathrm{X} 1.9$ & 0.390 & 0.196 & Valid \\
\hline 10. & $\mathrm{X} 1.10$ & 0.431 & 0.196 & Valid \\
\hline 11. & $\mathrm{X} 1.11$ & 0.539 & 0.196 & Valid \\
\hline 12. & $\mathrm{X} 1.12$ & 0.628 & 0.196 & Valid \\
\hline 13. & $\mathrm{X} 1.13$ & 0.569 & 0.196 & Valid \\
\hline 14. & $\mathrm{X} 1.14$ & 0.617 & 0.196 & Valid \\
\hline 15. & $\mathrm{X} 1.15$ & 0.695 & 0.196 & Valid \\
\hline 16. & $\mathrm{X} 1.16$ & 0.440 & 0.196 & Valid \\
\hline 17. & $\mathrm{X} 1.17$ & 0.621 & 0.196 & Valid \\
\hline 18. & $\mathrm{X} 1.18$ & 0.628 & 0.196 & Valid \\
\hline 19. & $\mathrm{X} 2.1$ & 0.777 & 0.196 & Valid \\
\hline 20. & $\mathrm{X} 2.2$ & 0.754 & 0.196 & Valid \\
\hline 21. & $\mathrm{X} 2.3$ & 0.779 & 0.196 & Valid \\
\hline 22. & $\mathrm{X} 2.4$ & 0.770 & 0.196 & Valid \\
\hline 23. & $\mathrm{X} 2.5$ & 0.676 & 0.196 & Valid \\
\hline 24. & $\mathrm{X} 2.6$ & 0.819 & 0.196 & Valid \\
\hline 25. & $\mathrm{Y} 1.1$ & 0.600 & 0.196 & Valid \\
\hline 26. & $\mathrm{Y} 1.2$ & 0.639 & 0.196 & Valid \\
\hline 27. & $\mathrm{Y} 2.1$ & 0.736 & 0.196 & Valid \\
\hline 28. & $\mathrm{Y} 2.2$ & 0.196 & Valid \\
\hline & & & & \\
\hline
\end{tabular}

Sumber: Data diolah, 2017.

Dari tabel 8 dapat diketahui bahwa seluruh item pernyataan yang diajukan kepada para responden adalah valid, karena seluruh r-hitung > r-tabel. Maka setiap setiap item pernyataan tersebut dapat dilanjutkan untuk penelitian selanjutnya.

2. Uji Reliabilitas

Hasil pengolahan data untuk uji reliabilitas sebagai berikut :

Tabel 9. Hasil Uji Reliabilitas

\begin{tabular}{|c|l|c|c|}
\hline No. & \multicolumn{1}{|c|}{ Variabel } & Cronbach Alpha & Keterangan \\
\hline 1. & Kualitas Makanan & 0,871 & Reliabel \\
\hline 2. & Harga & 0,856 & Reliabel \\
\hline 3. & Kepuasan Konsumen & 0,703 & Reliabel \\
\hline
\end{tabular}

Sumber: Data diolah, 2017.

Dari tabel 9 terlihat bahwa seluruh variabel yang diuji reliabel, karena cronbach alpha dari hasil uji reliabilitas semuanya $>0,600$.

\subsection{Hasil Analisis Data}

1. Uji Normalitas Data 
Dari hasil uji normalitas data diperoleh hasil bahwa populasi tersebar secara normal, yang berarti sampel yang diambil mewakili populasi. Uji normalitas dilakukan dengan menggunakan grafik normal probability plot. Normalitas terpenuhi karena jika nilai-nlai sebaran data terletak disekitar garis lurus.

Dependent Variable: Kepuasan Konsumen

2. Analisis Deskriptif

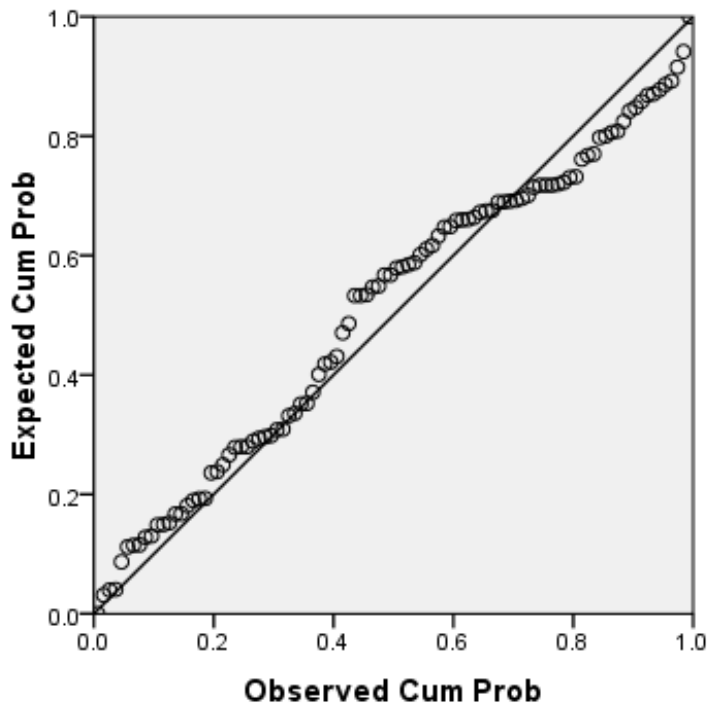

Gambar 2. Hasil Uji Normalitas

Deskripsi responden mengenai masing-masing item pernyataan pada setiap variabel dalam penelitian ini adalah sebagai berikut :

1. Kualitas Makanan

Hasil pengolahan data distribusi frekuensi dan TCR variabel produk :

Tabel 10. Distribusi Frekuensi dan TCR Variabel Kualitas Makanan

\begin{tabular}{|c|c|c|c|c|c|c|c|c|c|c|}
\hline \multirow{2}{*}{ Indikator } & \multirow{2}{*}{$\begin{array}{l}\text { No. } \\
\text { Butir }\end{array}$} & \multicolumn{5}{|c|}{ Pernyataan } & \multirow{2}{*}{$\mathbf{N}$} & \multirow{2}{*}{ Skor } & \multirow{2}{*}{ TCR } & \multirow{2}{*}{ Ket. } \\
\hline & & SS & $\mathbf{S}$ & BS & TS & STS & & & & \\
\hline \multirow{2}{*}{ Warna } & 1 & 36 & 40 & 20 & 4 & 0 & 100 & 368 & 73.6 & Cukup baik \\
\hline & 2 & 28 & 49 & 18 & 5 & 0 & 100 & 400 & 80 & Baik \\
\hline \multirow{2}{*}{ Penampilan } & 3 & 18 & 48 & 25 & 9 & 0 & 100 & 372 & 74.4 & Cukup baik \\
\hline & 4 & 26 & 49 & 18 & 5 & 2 & 100 & 392 & 78.4 & Cukup baik \\
\hline \multirow{2}{*}{ Porsi } & 5 & 27 & 41 & 21 & 11 & 0 & 100 & 384 & 76.8 & Cukup baik \\
\hline & 6 & 15 & 54 & 19 & 10 & 2 & 100 & 370 & 74 & Cukup baik \\
\hline \multirow{2}{*}{ Bentuk } & 7 & 24 & 46 & 27 & 3 & 0 & 100 & 391 & 78.2 & Cukup baik \\
\hline & 8 & 13 & 51 & 30 & 6 & 0 & 100 & 371 & 74.2 & Cukup baik \\
\hline \multirow{2}{*}{ Temperatur } & 9 & 17 & 41 & 24 & 13 & 5 & 100 & 352 & 70.4 & Cukup baik \\
\hline & 10 & 22 & 46 & 20 & 9 & 3 & 100 & 375 & 75 & Cukup baik \\
\hline \multirow{2}{*}{ Tekstur } & 11 & 22 & 47 & 23 & 7 & 1 & 100 & 382 & 76.4 & Cukup baik \\
\hline & 12 & 25 & 45 & 27 & 2 & 1 & 100 & 391 & 78.2 & Cukup baik \\
\hline \multirow{2}{*}{ Aroma } & 13 & 34 & 42 & 21 & 2 & 1 & 100 & 406 & 81,2 & Baik \\
\hline & 14 & 27 & 49 & 23 & 1 & 0 & 100 & 402 & 80,4 & Baik \\
\hline Tingkat & 15 & 33 & 46 & 18 & 3 & 0 & 100 & 409 & 81,8 & Baik \\
\hline
\end{tabular}


Polibisnis, Volume 9 No.2 Oktober 2017

\begin{tabular}{|l|c|c|c|c|c|c|c|c|c|c|}
\hline Kematangan & 16 & 26 & 48 & 17 & 7 & 2 & 100 & 389 & 77,8 & Cukup baik \\
\hline \multirow{2}{*}{ Rasa } & 17 & 43 & 42 & 12 & 3 & 0 & 100 & 425 & 85 & Baik \\
\cline { 2 - 10 } & 18 & 29 & 43 & 24 & 4 & 0 & 100 & 397 & 79,4 & Cukup baik \\
\hline
\end{tabular}

2. Harga

Hasil pengolahan data distribusi frekuensi dan TCR variabel harga :

Tabel 11. Distribusi Frekuensi dan TCR Variabel Harga

\begin{tabular}{|c|c|c|c|c|c|c|c|c|c|c|}
\hline \multirow{2}{*}{ Indikator } & \multirow{2}{*}{$\begin{array}{l}\text { No. } \\
\text { Butir }\end{array}$} & \multicolumn{5}{|c|}{ Pernyataan } & \multirow{2}{*}{$\mathbf{N}$} & \multirow{2}{*}{ Skor } & \multirow{2}{*}{ TCR } & \multirow{2}{*}{ Ket. } \\
\hline & & SS & $\mathbf{S}$ & BS & TS & STS & & & & \\
\hline \multirow{2}{*}{$\begin{array}{l}\text { Kesesuaian } \\
\text { harga produk } \\
\text { dengan kualitas }\end{array}$} & 1 & 32 & 47 & 14 & 6 & 1 & 100 & 403 & 80,6 & Baik \\
\hline & 2 & 26 & 49 & 18 & 6 & 1 & 100 & 393 & 78,6 & $\begin{array}{c}\text { Cukup } \\
\text { Baik }\end{array}$ \\
\hline \multirow{2}{*}{$\begin{array}{l}\text { Perbandingan } \\
\text { harga dengan } \\
\text { produk sejenis }\end{array}$} & 3 & 20 & 54 & 19 & 7 & 0 & 100 & 387 & 77,4 & $\begin{array}{c}\text { Cukup } \\
\text { Baik }\end{array}$ \\
\hline & 4 & 22 & 46 & 25 & 7 & 0 & 100 & 383 & 76,6 & $\begin{array}{c}\text { Cukup } \\
\text { Baik }\end{array}$ \\
\hline \multirow{2}{*}{$\begin{array}{l}\text { Kesesuaian } \\
\text { harga produk } \\
\text { dengan manfaat } \\
\text { yang didapatkan }\end{array}$} & 5 & 28 & 46 & 19 & 7 & 0 & 100 & 395 & 79 & $\begin{array}{c}\text { Cukup } \\
\text { Baik }\end{array}$ \\
\hline & 6 & 29 & 40 & 21 & 9 & 1 & 100 & 387 & 77,4 & $\begin{array}{c}\text { Cukup } \\
\text { Baik }\end{array}$ \\
\hline
\end{tabular}

Sumber: Data diolah, 2017.

3. Kepuasan Konsumen

Hasil pengolahan data distribusi frekuensi dan TCR variabel kepuasan konsumen :

Tabel 12. Distribusi Frekuensi dan TCR Variabel Kepuasan Konsumen

\begin{tabular}{|c|c|c|c|c|c|c|c|c|c|c|}
\hline \multirow{2}{*}{ Indikator } & \multirow{2}{*}{$\begin{array}{l}\text { No. } \\
\text { Butir }\end{array}$} & \multicolumn{5}{|c|}{ Pernyataan } & \multirow{2}{*}{$\mathbf{N}$} & \multirow{2}{*}{ Skor } & \multirow{2}{*}{ TCR } & \multirow{2}{*}{ Ket. } \\
\hline & & SS & $\mathbf{S}$ & BS & TS & STS & & & & \\
\hline \multirow{2}{*}{$\begin{array}{l}\text { Harapan } \\
\text { pelanggan }\end{array}$} & 1 & 26 & 51 & 18 & 3 & 2 & 100 & 396 & 79,2 & $\begin{array}{c}\text { Cukup } \\
\text { Baik }\end{array}$ \\
\hline & 2 & 21 & 45 & 26 & 7 & 1 & 100 & 378 & 75,6 & $\begin{array}{c}\text { Cukup } \\
\text { Baik }\end{array}$ \\
\hline \multirow{2}{*}{$\begin{array}{l}\text { Penilaian } \\
\text { kepuasan } \\
\text { pelanggan }\end{array}$} & 3 & 28 & 49 & 19 & 4 & 0 & 100 & 401 & 80,2 & Baik \\
\hline & 4 & 27 & 43 & 22 & 7 & 1 & 100 & 388 & 77,6 & $\begin{array}{c}\text { Cukup } \\
\text { Baik }\end{array}$ \\
\hline
\end{tabular}

Sumber: Data diolah, 2017.

3. Uji Regresi

Untuk mendapatkan gambaran pengaruh dari variabel independent terhadap variabel dependent, maka dapat dilihat pada tabel berikut ini :

Tabel 13. Hasil Uji Regresi

Coefficients $^{\mathrm{a}}$

\begin{tabular}{|c|c|c|c|}
\hline & Unstand & Coefficients & $\begin{array}{l}\text { Standardized } \\
\text { Coefficients }\end{array}$ \\
\hline Model & B & Std. Error & Beta \\
\hline
\end{tabular}




\begin{tabular}{|l|r|r|r|r|r|}
\hline $1 \quad$ (Constant) & 3.943 & 1.966 & & 2.006 & .048 \\
Kualitas Makanan & .097 & .036 & .302 & 2.685 & .009 \\
Harga & .202 & .079 & .288 & 2.564 & .012 \\
\hline
\end{tabular}

a. Dependent Variable: Kepuasan Konsumen

Sumber: Data dilolah, 2017.

Berdasarkan hasil uji regresi di atas, maka persamaan regresi linear berganda dapat diformulasikan sebagai berikut :

$Y=3,943+0,097 X_{1}+0,202 X_{2}+e$

Dari persamaan regresi di atas dapat dijabarkan sebagai berikut :

1. Nilai konstanta adalah 3,943, artinya tanpa adanya pengaruh kualitas makanan dan harga, maka kepuasan konsumen pada pedagang Langkitang kaki lima di kawasan objek wisata Pantai Padang sudah ada sebesar 3,943.

2. Nilai koefisien regresi kualitas makanan adalah 0,097 , artinya setiap peningkatan satu satuan kualitas makanan, maka kepuasan konsumen pada pedagang Langkitang kaki lima di kawasan objek wisata Pantai Padang meningkat sebesar 0,097. Dengan asumsi variabel selain kualitas makanan dianggap tetap atau tidak mengalami perubahan.

3. Nilai koefisien regresi harga adalah 0,202, artinya setiap peningkatan satu satuan harga, maka kepuasan konsumen pada pedagang Langkitang kaki lima di kawasan objek wisata Pantai Padang meningkat sebesar 0,202. Dengan asumsi variabel selain harga dianggap tetap atau tidak mengalami perubahan.

4. Uji t-Statistik

Untuk mengetahui ada atau tidaknya pengaruh variabel independent terhadap variabel dependent secara parsial dapat dilihat pada tabel berikut ini :

Tabel 14. Hasil Uji t-Statistik

Coefficients $^{\mathrm{a}}$

\begin{tabular}{|c|c|c|c|c|c|c|}
\hline \multirow{2}{*}{\multicolumn{2}{|c|}{ Model }} & \multicolumn{2}{|c|}{ Unstandardized Coefficients } & \multirow{2}{*}{$\begin{array}{c}\begin{array}{c}\text { Standardized } \\
\text { Coefficients }\end{array} \\
\text { Beta }\end{array}$} & \multirow[b]{2}{*}{$\mathrm{T}$} & \multirow[b]{2}{*}{ Sig. } \\
\hline & & $\mathrm{B}$ & Std. Error & & & \\
\hline \multirow[t]{3}{*}{1} & (Constant) & 3.943 & 1.966 & & 2.006 & .048 \\
\hline & Kualitas Makanan & .097 & .036 & .302 & 2.685 & .009 \\
\hline & Harga & 202 & .079 & .288 & 2.564 & .012 \\
\hline
\end{tabular}

a. Dependent Variable: Kepuasan Konsumen

Sumber: Data diolah, 2017.

Berdasarkan hasil uji t-statistik di atas, dapat jabarkan bahwa :

1. Hasil uji t untuk pengaruh kualitas makanan terhadap kepuasan konsumen pada pedagang Langkitang kaki lima di kawasan objek wisata Pantai Padang menghasilkan t-hitung 2,685, di mana nilai tersebut lebih besar dari t-tabel 1,661, dan signifikansi 0,009 lebih kecil dari level of significant $(\alpha) 0,05$. Dapat disimpulkan bahwa kualitas makanan berpengaruh signifikan terhadap kepuasan konsumen pada pedagang Langkitang kaki lima di kawasan objek wisata Pantai Padang. 
2. Hasil uji t untuk pengaruh harga terhadap kepuasana konsumen pada pedagang Langkitang kaki lima di kawasan objek wisata Pantai Padang menghasilkan t-hitung 2,564, di mana nilai tersebut lebih besar dari t-tabel 1,661, dan signifikansi 0,012 lebih kecil dari level of significant $(\alpha) 0,05$. Dapat disimpulkan bahwa harga berpengaruh signifikan terhadap kepuasan konsumen pada pedagang Langkitang kaki lima di kawasan objek wisata Pantai Padang.

5. Uji F

Untuk mengetahui signifikansi pengaruh variabel-variabel independent secara bersama-sama (simultan) terhadap variabel dependent dapat dilihat pada tabel berikut ini :

Tabel 15. Hasil Uji F

ANOVA $^{\mathrm{D}}$

\begin{tabular}{|ll|r|r|r|r|r|}
\hline Model & & Sum of Squares & Df & Mean Square & F & Sig. \\
\hline 1 & Regression & 226.789 & 2 & 113.395 & 19.496 & $.000^{\mathrm{a}}$ \\
& Residual & 564.171 & 97 & 5.816 & & \\
& Total & 790.960 & 99 & & & \\
\hline
\end{tabular}

a. Predictors: (Constant), Harga, Kualitas Makanan

b. Dependent Variable: Kepuasan Konsumen

Sumber: Data diolah, 2017.

Berdasarkan tabel hasil uji $\mathrm{F}$ di atas dapat diketahui bahwa F-hitung adalah 19,496 lebih besar dari F-tabel yaitu sebesar 3,09, dan signifikansi 0,000 lebih kecil dari level of significant $(\alpha)$ 0,05. Dapat disimpulkan bahwa kualitas makanan dan harga secara bersama-sama (simultan) berpengaruh terhadap kepuasan konsumen pada pedagang Langkitang kaki lima di kawasan objek wisata Pantai Padang.

6. Koefisien Determinasi $\left(\mathrm{R}^{2}\right)$

Hasil koefisien determinasi $\left(\mathrm{R}^{2}\right)$ dapat dilihat pada tabel berikut ini :

Tabel 16. Hasil Koefisien Determinasi $\left(\mathbf{R}^{2}\right)$ Model Summary

\begin{tabular}{|c|c|c|c|c|c|c|c|c|c|}
\hline \multirow[b]{2}{*}{ Model } & \multirow[b]{2}{*}{$\mathrm{R}$} & \multirow[b]{2}{*}{ R Square } & \multirow[b]{2}{*}{$\begin{array}{l}\text { Adjusted R } \\
\text { Square }\end{array}$} & \multirow[b]{2}{*}{$\begin{array}{c}\text { Std. Error of the } \\
\text { Estimate }\end{array}$} & \multicolumn{5}{|c|}{ Change Statistics } \\
\hline & & & & & $\begin{array}{l}\text { R Square } \\
\text { Change }\end{array}$ & F Change & df1 & $\mathrm{df2}$ & Sig. F Change \\
\hline 1 & $.535^{\mathrm{a}}$ & .287 & .272 & 2.41168 & .287 & 19.496 & 2 & 97 & .000 \\
\hline
\end{tabular}

a. Predictors: (Constant), Harga, Kualitas Makanan

b. Dependent Variable: Kepuasan Konsumen

Sumber: Data diolah, 2017.

Berdasarkan tabel 16 dapat diketahui bahwa koefisien determinasi adalah 0,272, berarti kualitas makanan dan harga mempengaruhi kepuasan konsumen pada pedagang Langkitang kaki lima di kawasan objek wisata Pantai Padang sebesar $27,2 \%$. Sisanya $72,8 \%$ dipengaruhi oleh variabel lain di luar dari model penelitian ini. Misalnya variabel bauran pemasaran $(4 P)$ lainnya, atau lingkungan sosio-budaya seperti, keluarga, sumber informasi, sumber 
nonkomersial lain, kelas sosial, subbudaya dan budaya (Schiffman dan Kanuk, 2004:8).

\section{SIMPULAN DAN SARAN}

\subsection{Simpulan}

Dari hasil pengolahan data dan pembahasan terhadap hasil penelitian yang penulis lakukan, dapat diambil kesimpulan sebagai berikut :

1. Kualitas makanan pedagang Langkitang kaki lima di kawasan objek wisata Pantai Padang berpengaruh signifikan terhadap kepuasan konsumen.

2. Harga yang ditawarkan pedagang Langkitang kaki lima di kawasan objek wisata Pantai Padang berpengaruh signifikan terhadap kepuasan konsumen.

3. Kualitas makanan dan harga secara bersama-sama berpengaruh signifikan terhadap kepuasan konsumen pedagang Langkitang kaki lima di kawasan objek wisata Pantai Padang.

\subsection{Saran}

Berdasarkan hasil pada penelitian, untuk meningkatkan kepuasan konsumen, maka pedagang Langkitang kaki lima di kawasan objek wisata Pantai Padang dapat melakukan beberapa hal sebagai berikut :

1. Dari sisi kualitas makanan, diharapkan dapat dengan konsisten menyajikan Langkitang kepada konsumen dalam keadaan tempratur hangat.

2. Dari sisi harga, Langkitang yang ditawarkan pedagang sebaiknya tidak lebih mahal jika dibandingkan dengan Langkitang yang dijual di tempat lain.

3. Dari sisi kepuasan konsumen, pedagang harus meningkatkan nilai manfaat dari produk dan layanan, sehingga harapan terhadap harga Langkitang yang ditawarkan sesuai dengan nilai manfaat yang diinginkan oleh konsumen.

\section{DAFTAR PUSTAKA}

Barner, James G. 2001. Secrets of Costumer Relationship Management: Rahasia Manajemen Hubungan Konsumen. Yogyakarta: Penerbit Andi.

Fiani, S., Margaretha, Japarianto, Edwin. Analisa Pengaruh Food Quality dan Brand Image Terhadap Keputusan Pembelian Roti Kecik Toko Roti Ganep's di Kota Solo. Jurnal Manajemen Pemasaran, Vol. 1, No. 1. 2012.

Ghozali, Imam. 2005. Aplikasi Analisis Multivariat dengan Program SPSS. Semarang: Penerbit Unversitas Diponegoro.

Kertajaya, Hermawan. 2007. Hermawan Kartajaya on Segmentation. Bandung: PT. Mizan Pustaka.

Kotler, Philip, Keller, Kevin Lane. 2009. Manajemen Pemasaran, Jilid Satu, Edisi Ketiga Belas. Alih Bahasa. Jakarta: Penerbit Erlangga.

, Philip, Keller, Kevin Lane. 2009. Manajemen Pemasaran, Jilid Dua, Edisi Ketiga Belas. Alih Bahasa. Jakarta: Penerbit Erlangga.

Lovelock dan Wirtz. 2011. Pemasaran Jasa. Manusia, Teknologi dan Strategi. Jilid I. Jakarta: Penerbit Erlangga.

Marlhotra, Naresh K. 2005. Riset Pemasaran, Pendekatan Terapan, Jilid Satu, Edisi Keempat. Alih Bahasa. Jakarta: Indeks.

Peraturan Menteri Dalam Negeri, Nomor 41, Tahun 2012, tentang Pedoman Penataan dan Pemberdayaan Pedagang Kaki Lima. 
Putra, Hafrizal Okta Ade. Pengaruh Bauran Pemasaran Jasa Terhadap Keputusan Pembelian Kartu Perdana Prabayar XL di Kota Padang. Jurnal Manajemen dan Kewirausahaan (ISSN: 2086-5031), Vol. 3, No. 1. Januari 2012.

Sakaran, Uma. 2006. Metodologi Penelitian Untuk Bisnis, Edisi 4, Buku 1. Jakarta: Salemba Empat.

Sari, Dianing. "Bondan Winarno: Jajanan Kaki Lima Itu Budaya", tempo.co, (http://www.tempo.co/read/news/2013/03/15/201467291/Bondan-WinarnoJajanan-Kaki-Lima-Itu-Budaya, 15 Maret 2013, diakses 20 April 2016).

Sari, Maya Purnama. "Ini Dia Khasiat Langkitang dan Pensi", katasiapaa.blogspot.co.id, (http://kata-siapaa.blogspot.co.id/2015/04/ini-dia-khasiatlangkitang-dan-pensi.html, 25 April 2015, diakses 28 Mei 2016).

Schiffman, Leon G., Kanuk, Leslie Lazar. 2004. Perilaku Konsumen, Edisi Ketujuh. Alih Bahasa. Jakarta: Indeks.

Santoso, Singgih. 2003. Buku Latihan SPSS Statistik Parametrik. Jakarta: Penerbit PT. Elex Media Komputindo Kelompok Gramedia.

Sugiyono. 2004. Metode Penelitian Bisnis. Bandung: CV. Alfabeta. 